\title{
Penegakan Hukum Lingkungan Bidang Pertambangan Batubara dan Penguatan Lembaga Masyarakat Adat
}

\author{
Afif Syarif $^{1}$, Eko Nuriyatman ${ }^{2}$ \\ Fakultas Hukum Universitas Jambi, Indonesia \\ Perum Bambu Apung 2 Blok B.06, Desa Sungai Duren, Kecamatan Jambi Luar Kota, Indonesia \\ Correspondence email: unjaafifsyarif@gmail.com, Email: ekonuriyatman90@gmail.com
}

\begin{abstract}
Abstrak. Artikel ilmiah ini membahas mengenai penegakan hukum lingkungan di bidang pertambangan batubarara dan penguatan lembaga masyarakat adat di Kabupayten Bungo. Metode pendekatan penelitian yang digunakan dalam artikel ilmiah ini adalah yuridis normatif dan yuridis empiris untuk dapat menemukan konsep penegakan terhadap hukum lingkungan dalam bidang pertambangan batubara dengan mengkaji asas-asas hukum pertambangan demi kesejahteraan masyarakata. Hakekat hukum lingkungan seharusnya dapat mencegah terjadinya pencemaran dan kerusakan lingkungan dan keberadaan kelembagaan masyarakat adat di Kabupaten Bungo belum berfungsi dalam penegakan hukum lingkungan bidang usaha pertambangan batubara. Oleh karena itu pemerintah daerah Kabupaten Bungo perlu melakukan penguatan kelembagaan masyarakat adat supaya dapat berfungsinya melakukan penegakan hukum lingkungan terhadap pertambangan batubara untuk meningkatkan kesejahteraan masyarakat di Kabupaten Bungo.
\end{abstract}

Kata Kunci : Penegakan Hukum, Hukum Lingkungan, Tambang Batubara

\begin{abstract}
This scientific article discusses the enforcement of environmental law in the field of coal mining and the strengthening of indigenous community institutions in Bungo Regency. The research approach method used in this scientific article is normative juridical and empirical juridical to be able to find the concept of enforcement of environmental law in the field of coal mining by examining the principles of mining law for the welfare of the community. The nature of environmental law should be able to prevent the occurrence of pollution and environmental damage and the existence of institutions of indigenous peoples in Bungo District has not functioned in the enforcement of environmental law in the field of coal mining business. Therefore the Bungo District government needs to strengthen the institutional of indigenous peoples so that it can function to enforce environmental law against coal mining to improve the welfare of the people in Bungo District.
\end{abstract}

Keywords: Law Enforcement, Environmental Law, Coal Mine

\section{PENDAHULUAN}

Sebagai mana yang kita ketahui bahwa pertambangan batubara merupakan suatu bahan galian yang sangat strategis dan hampir berada di seluruh wilayah Indonesia tidak terkecuali di Kabupaten Bungo Provinsi Jambi. Saat ini perkembangan tambang batubara semakin pesat dikarenakan semakin banyaknya galian tambang baru yang sampai saat ini belum dapat di olah secara maksimal untuk kemakmuran masyarakat. Kegiatan usaha pertambangan batubara saat ini menyumbangkan keuntungan yang sangat besar baik bagi pemerintah untuk dapat meningkatkan devisa negara dari sektor pertambangan.

Perkembangan pertambangan batubara di Kabupaten Bungo semakin dengan ditemukannya tambang-tambang baru, namun perkembangan yang pesat tidak diimbangi dengan pengelolaan lingkungan yang baik. Oleh karena itulah muncul persoalan kerusakan lingkungan terhadap eksplorasi tambang disekitar lokasi pertambangan tersebut. Sebaliknya, pengusaha dan pekerja tambang, sulit untuk diminta pertanggung jawaban atas kerusakan lingkungan yang ditimbulkan akibat kegiatan eksploirasi tambang dan yang lebih ironisnya keadilan sulit diwujudkan, konsekuensinya kesenjangan sosial sulit dihindari dilokasi pertambangan batubara di kabupaten Bungo.

Pada bidang pertambangan batubara penegakan hukum lingkungan sulit terwujud karena dipengaruhi berbagai faktor, baik bersifat yuridis maupun non yuridis. Bersifat yuridis (undang-undang) adalah berkaitan instrument pengaturan perundang-undangan mengenai penegakan hukum terhadap kegiatan pertambangan batu baru, serta penerapan sanksi terhadap pelanggaran di bidang usaha pertambangan batubara implementasinya yang masih rancu. Kerancuan ini muncul dikarenakan adanya pemberian kewenangan yang begitu luas kepada pemerintahan kabupaten dan kota yang muncul pada Undang-Undang Nomor 4 Tahun 2009 Tentang Mineral Batubara (UU Minerba).

Sedangkan di bidang non yuridis adalah berkaitan kuatnya kedudukan bupati sebagai kepala daerah akibat perobahan sistem pemerintah daerah yang sentralistik kepada pemerintahan daerah desentralistik dis aat masih berlakuknya Undang-Undang Nomor 32 Tahun 2004 Tentang Pemeritahan Daerah. Namun setelah berlakunya undang-undang baru, yaitu Undang-Undang Nomor 23 Tahun 2014 Tentang Pemerintahan Daerah (selanjutnya

\footnotetext{
${ }^{1}$ Dosen Fakultas Hukum Universitas Jambi.

${ }^{2}$ Pengamat Kebijakan Hukum Lingkungan.
} 
disebut UU Pemda) semua perizinan pertambangan batubara terpusat di pemerintahan Provinsi. Persoalannya Izin Usaha Pertambangan (IUP) batubara dan Wilayah Izin Usaha Pertambangan (WIUP) batubara perizinannya dikeluarkan oleh bupati sebelum berlakunya UU Pemda terbaru, hal inilah yang menimbulkan pesoalan dalam penegakan hukum lingkungan di bidang usaha pertambangan batubara khususnya di kabupaten Bungo.

Pertambangan batubara adalah sumber daya alam tak terbarukan yang mempunyai peranan sangat penting dalam memenuhi hajat hidup orang banyak serta memberi nilai tambah secara nyata bagi perekonomian nasional untuk mewujudkan kemakmuran dan kesejahteraan rakyat. ${ }^{3}$ Dengan demikian tidak dapat disangkal lagi bahwa batubara merupakan sumber daya alam dapat meningkatkan kesejahteraan masyarakat secara menyeluruh dan diharapkan adanya keadilan bagi seluruh masyarakat yang ada dalam mengelola sumber daya ala mini secara baik dan tidak menggaggu keseimbangan ligkungan yang ada, dalam hal ini pengelolaannya harus dikuasai oleh sebagai mana yang terdapat di dalam Pasal 33 ayat (3) Undang-Undang Dasar 1945.

Pengertian dikuasai oleh negara mengandung makna, tidak diartikan secara khusus. Namun secara etimologis penafsiran dikuasai oleh negara adalah berkuasa dan/atau kekuasaan atas tambang batubara, sedangkan arti dari penguasaan merupakan proses perbuatan menguasai adan/tau mengusahakan. ${ }^{4}$ Dengan demikian pengertian menguasai berdasarkan Pasal 33 ayat (3) Undang-Undang Dasar Negara Republik Indonesia 1945 merupakan dasar konstitusional Hak Penguasaan Negara (HPN) atas bumi, air dan kekayaan alam yang terkandung di dalamnya termasuk batubara.

Menurut Salim HS, HPN atas tambang batubara adalah mewujudkan kewajiban negara untuk kemakmuran rakyat sebesar-besarnya atas bahan galian tambang tersebut. ${ }^{5}$ Persoalannya, dalam pemanfaatan bahan galian tambang batubara di daerah masih jauh dari harapan meningkatkan kemakmuran rakyat, ${ }^{6}$ bahkan hak-hak rakyat atas bumi dirampas untuk kepentingan pengusaha yang berlindung atas nama kepentingan negara melalui perizinan dengan bentuk bentuk Kuasa Pertambangan (KP) dan/atau IUP di daerah. ${ }^{7}$ Dalam kaitan dengan otonomi daerah, seiring diterbitnya UU Minerba yang mana menerangkan bahwa bupati sebagai kepala daerah mempunyai kekuasaan terhadap IUP batubara dengan dasar otonomi daerah. Dalam konteks ini Abrar Saleng mengatakan, carut marutnya sektor pertambangan batubara di Indonesia merupakan salah satu perubahan sistem pemerintahan sentralistik menjadi desentralistik berdasarkan UU Pemda.

Perubahan sistem pemerintahan ini berdampak pada perubahan pengaturan mengenai pengelolaan pertambangan dimulai dengan diterbitkannya Peraturan Pemerintah Nomor 75 Tahun 2001 yang merupakan penganti Peraturan Pemerintah Nomor 32 Tahun 1969 tentang Pelaksanaan Undang-Undang Pokok Pertambangan Nomor 11 Tahun 1967. Berdasarkan Peraturan Pemerintah Nomor 75 tersebut banyak terjadi euphoria di bidang pertambangan batubara. Dimana pemerintah daerah berlomba-lomba menerbitkan izin KP karena merasa punya wewenang. ${ }^{8}$ Dikarenakan euporia tersebut banyak dari kepala daerah yang melakukan obral izin KP pada daerahnya yang memiliki potensi sumber daya alam mineral batubara, dengan dalih meningkatkan pendapatan daerah. ${ }^{9}$ Hal seperti inilah yang menggaggu keseimbangan alam tanpa memperhatikan instrumen perizinan yang dikeluarkan oleh masing-masing kepala daerah.

Berdasarkan hal di atas didalam artikel ilmiah ini akan membahas mengenai bagaimana konsep penegakan hukum lingkungan dapat diterapkan dalam kelembagaan masyarakat adat dan mengenai model penguatan kelembagaan masyarakat adat berkaian dengan penegakan hukum lingkungan.

\section{METODE PENELITIAN}

${ }^{3}$ Soni Heri Prasetyo, "Menata IUP, Membenahi Industri Minerba. Artikel, Minerba”, majalah Dirjen Minerba, Jakarta, Maret, No.7, Vol.5, (2004), hlm. 124.

${ }^{4}$ Abrar Saleng, Kuasa Pertambangan Dalam Perspektif Hukum Administrasi Negara. Dalam Buku Dimensi-dimensi Pimikiran Hukum Administrasi Negara, (Yogyakarta: UII Press, 2001), hlm. 146.

5 Salim HS, "Hak Menguasai Negara atas Minerba, Pasca Berlakunya Undang-undang Minerba". Jurnal Konstitusi, No.3,Vol.9, (2002), hlm. 126.

${ }^{6}$ Martha Pigone, "Politik Hukum Pertambangan Indonesia dan Pengaruh pada Pengelolaan Lingkungan Hidup di Era Otonomi Dearah", Jurnal Hukum, Jakarta, Desember, No.3, Vol.15, (2003), hlm. 27.

${ }^{7}$ Fenty U.Puluhulawa, "Kewenangan Perizinan Dalam Pengelolaan Lingkungan Pada Usaha Pertambangan", Jurnal Hukum, Fakultas Hukum Universitas Hasanundin, No.5, Vol.IX, (2014), hlm. 76.

8 Hayatul Ismi, "Pengelolaan Sumber Daya Alam Mineral dan Batubara", Jurnal Ilmu Hukum Universitas Riau, No.2, Vol.4, (Februari 2017), hlm. 102.

9 Salim HS, "Hak Menguasai Negara atas Minerba, Pasca Berlakunya Undang-undang Minerba", Jurnal Konstitusi, No.3, Vol.9, (2002), hlm. 126. 
Lokasi peneitian dalam artikel ilmiah ini adalah daerah lokasi tambang batubara yang terdapat di Kabupaten Bungo. Untuk menetukan lokasi disetiap tambang batubara dilakukan pengamatan dan pengkajian melalui koordinasi dengan pemerintah Kabupaten Bungo, Unit Koperasi Tambang Batubara kabupaten Bungo dan Ketua Lembaga Adat Kabupaten Bungo. Dalam penelitian ini yang peneliti lakukan adalah melakukan pengamatan terhadap aturan tradisional dan pola yang berlaku berdasarkan oleh kepercayaan masyarakat dalam hal pertambangan batubara pada Kabupaten Bungo. Metode penedekatan penelitian adalah dengan menggunakan metode normatif melalui pendekatan deskriptif analistis yang memiliki tujuan untuk dapat mengetahui eksistensi dalam hal bidang hukum adat dalam penegakan terhadap hukum lingkungan.

Pada artikelm ilmiah ini peneliti mengkaji dan mengidentifikasi kaedah-kaedah hukum adat terhadap sumber daya alam batubara, pendekatan sosiologis, yaitu mengkaji hubungan masyarakat lokal/adat terhadap keberadaan tambang batubara sebagai hak-hak adat dan pendekatan historis, yaitu mengkaji sejarah hak-hak adat atas tambang batubara bagaimana hubungan genologis masyarakat hukum adat berhubungan dengan sumber daya alam. Sumber data, data primer diperoleh melalui hasil survey dilapangan dengan pengamatan lansung dilakukan melalui wawancara terhadap tetua adat, masyarakat, tokoh adat pada daerah sekitar galian tambang batubara serta kepada kepala desa sebagai pejabat tertinggi di suatu desa. Sedangkan data sekunder melalui kajian kepustakaan serta dari berbagai bahan bacaan yang relevan serta seluruh peraturan perundang-undangan yang mendasari pertambangan batubara.

\section{HASIL DAN PEMBAHASAN}

\section{Penegakan Hukum Terhadap Kegiatan Pertambangan di Kabupaten Bungo}

Secara tegas UU Minerba telah memberikan kewenangan terhadap daerah provinsi, kabupaten dan kota untuk dapat melakukan pengelolaan terhadap kegiatan pertambangan batubara, yang mana di atur dalam Pasal 6, Pasal 7 dan Pasal 8 UU Minerba, yang mana hal ini belum diatur secara rinci dan detail oleh undang-undang sebelumnya. Berdasarkan UU Minerba tersebut pemerintah pusat diberikan kewenangan untuk dapat menata kembali regulasi dan dalam hal bidang perizinan dalam sektor pertambangan, yang mana memiliki tujuan KP yang digantikan menjadi IUP berdasarkan hal tersebut terjadilah perubahan kewenangan pembagian kekuasaan antara pemerintah pusat dan pemerintah daerah dalam hal pengelolaan terhadap penggalian pertambangan batubara.

Pelaksanaan rekonsiliasi atau penetapan Clear and Clean $(\mathrm{CnC})$ serta Non $\mathrm{CnC}$ terhadap KP menjadi IUP belum dilakukan secara benar. $\mathrm{CnC}$ dimaksudkan agar tidak ada peraturan yang tumpang tindih dan perizinan sesuai dengan peraturan yang berlaku, dalam hal ini berkaitan dengan IUP yang mana status izin nya sudah benar dan tidak menyalahi aturan serta wilayah izin pertambangan tidak terjadinya tumpang tindih dengan perusahaan/IUP lain serta wilayah konservasi alam dan dalam hal $\mathrm{CnC}$ ini pihak yang berhak mengajukan $\mathrm{CnC}$ adalah ESDM masing-masing kabupaten/kota.

Permasalahan penetapan status KP menjadi IUP berdasarkan CnC sampai dengan saat ini belum dapat menyelesaikan permasalahan yang ada, bahkan jika kita cermati dan analisis dapat menimbulkan permasalahan yang besar, karena kecenderungan saat ini masyarakat lebih percaya pada fakta yang substantif atau lazim disebut dengan kebenaran yang material, dari pada formalistik administratif yang disahkan oleh seorang pejabat tata usaha negara terhadap unsur pemerintah daerah.

Pada kajian penegakan hukum lingkungan pada bidang usaha pertambangan batubara berdasarkan oada UU Minerba yang tekah mengatur secara rinci dari kewenangan Pemerintah, baik itu pemerintah provinsi, kabupaten/kota dalam bidang penegakan terhadap hukum lingkungan pada bidang pertambangan batubara. Pengaturan tersebut terdapat dalam Pasal 6 UU Minerba yang menjelaskan bahwa pemerintah pusat memiliki wewenang dalam hal pengelolaan pertambangan batubara, yang berkaitan dengan penetapan terhadap kebijakan nacional. Adanya peraturan perundang-undangan, digunakan untuk melakukan penetapan terhadap standar nasional, yang meliputi:

1. Penetapan sistem perizinan;

2. Penetapan WP;

3. Pemberian IUP lintas wilayah propinsi;

4. Pemberian IUP yang berdampak terhadap lingkungan langsung dalam hal lintas provinsi;

5. Pemberian IUPK Eksplorasi; dan

6. IUPK Operasi Produksi.

Berkaitan dengan penegakan terhadap hukum lingkungan bidang usaha tambang batubara berdasarkan UU Minerba, yang dilakukan secara terpadu secara khusus diatur dalam Peraturan Pemerintah Nomor 24 Tahun 2012 tentang Pelaksanaan Usaha Pertambangan Mineral, pada Pasal 6 Peraturan Pemerintah tersebut mengatur bahwa IUP diberikan oleh meteri, gubernur, atau bupati dan walikota sesuai dengan kewenangan yang dimiliki oleh masingmasing pimpinan yang berdasarkan oleh surat permohonan yang diajukan baik oleh koperasi, perorangan dan badan usaha. Dalam hal ini badan usaha dapat berupa badan usaha swasta maupun Badan Usaha Milik Negara (BUMN) maupun Badan Usaha Milik Daerah (BUMD), namun dalam hal badan usaha swasta meliputi badan usaha dalam 
rangka penanaman modal dalam negeri, badan usaha swasta dalam hal penanaman modal asing dan dalam hal penanaman modal oleh badan usaha asing hanya dapat diberikan IUP oleh Menteri. IUP yang diberikan berdasarkan surat pengajuan tersebut dapat diberikan apabila telah memiliki Wilayah Izin Usaha Pertambangan (WIUP) yang mana dalam satu WIUP dapat diberikan lebih dari satu IUP.

Berdasarkan Pasal 6 Peraturan Pemerintah tersebut terlihat pengaturan kewenangan dari IUP dan WIUP batubara di daerah dititik beratkan kepada badan usaha, baik milik pemerintah ataupun swasta dalam rangka penanam modal dalam negeri maupun luar negeri setelah mendapat WIUP dan diberikan satu IUP. Persoalannya yang ada adalah Kabupaten Bungo adalah IUP yang ada saat ini tersebar dibeberapa kecamatan adalah berdasarkan KP yang diterbitkan oleh Bupati, tanpa memperhatikan isi Pasal 6 Peraturan Pemerintah tersebut.

Ketentuan tersebut, apabila dikaji dalam sistem hukum pertambangan Indonesia terhadap KP/IUP batubara yang dikeluarkan oleh Bupati Bungo di Provinsi Jambi adalah sesuai dengan perataruan perundang-undangan otonomi daerah, akan tetapi bertentangan dengan Undang-Undang Minerba. Ketentuan ini memunculkan konflik norma, dalam kaitan ini Abrar Saleng mengatakan, dalam sistem hukum Indonesia apabila terjadi tumpang tindih peraturan perundangan, maka kembali pada substansinya dalam konteks ini Undang-Undang Minerba.

Peraturan Pemerintah Nomor 24 Tahun 2012 menjelaskan bahwa, setelah berlakunya UU Minerba yang disahkan pada tanggal 12 Januari 2009 tidak ada lagi istilah KP namun berganti menjadi IUP. Hal ini diatur secara jelas di dalam Pasal 174 UU Minerba 2009 yang mana menyisakan pekerjaan rumah besar untuk pemerintah, yaitu peraturan pelaksana daru UU Minerba harus segera ditetapkan dalam jangka waktu satu tahun setelah UU Minerba diterbitkan. Dalam hal ini Meneri ESDM mengeluarkan Surat Edaran No.03.e/31/DJB/2009 Tentang Perizinan Pertam yang disahkan pada tanggal 30 Januari 2009, yang mana didalamya menyebutkan bahwa KP yang telah ada sebelum disahkan UU Minerba tetap berlaku sampai dengan berakhirnya izin tersebut dan selanjutnya di sesuaikan dengan IUP paling lama satu tahun semenjah UU Minerba disahkan.

KP yang dikeluarkan setelah tanggal 12 Januari 2009 secara otomatis tidak sah. Berdasarkan hal tersevut perlu dilakukan pengalihan ke IUP berdasarkan Pasal 93 ayat (3) Undang-Undang Minerba, artinya Bupati sesuai kewenangannya diberikan kuasa untuk pengalihan nama usaha pertambangan dari KP menjadi IUP. Di Provinsi Jambi terdapat 377 IUP batubara dan hampir 60\% IUP tersebut status KP yang belum clean and clear. Artinya terdapat permasalahan dalam perizinan KP menjadi IUP seperti, lokasi KP/IUP dikawasan yang tidak boleh untuk pertambangan batubara ; masalah perpajakan dan masalah tidak ada pembayaran royalti kepada negara serta izin lingkungan dan Amdal

Setelah berlakunya UU Minerba dan Peraturan Pemerintah Nomor 24 Tahun 2012 persoalanya semakin kompleks, pada hal tujuan pemerintah mengeluarkan Peraturan Pemerintah Nomor 23 Tahun 2010 adalah diharapkan akan membawa perubahan yang cukup signifikan terhadap kewenangan daerah dalam pengeloan KP menjadi IUP di kabupaten Bungo. Menyikapi permasalah KP menjadi IUP di Bungo dalam kaitan kewenangan daerah, umumnya rata-rata disetiap kabupaten pengahasil tambang batubara di Kabupaten Bungo banyak yang bermasalah, seperti perusahan tambang batubara yang tumpang tindih dan berada dikawasan hutan lindung, seperti PT Antam dan lainlain. Kemudian tumpang tindih dengan lahan masyarakat yang akan memicu konflik. Dari hasil kajian penulis sekitar $60 \% \mathrm{KP} / \mathrm{IUP}$ bermasalah dan/atau non $\mathrm{CnC}$, artinya perizinan KP/IUP batubara tersebut tidak sesuai dengan prosedur perizinan usaha tambang batubara berdasarkan peraturan yang berlaku di Kabupaten Bungo.

Dalam hal penegakan hukum lingkungan terhadap usaha tambang batubara di kabupaten Bungo, terjadinya politik desentralisasi yang telah memberikan kerenangan dari pemerintah pusat kepada pemerintah daerah memberikan kewenangan dan posisindari kepala daerah sangat berkuasa. Bahkan ada dugaan telah terjadi kolusi antara lembaga pemerintah di daerah dengan elit lokal dalam pemberian konsesi kepada perusahaan untuk mendapatkan kuasa pertambangan. Akhirnya kongkalikong dalam penegakan hukum terhadap kejahatan tambang batubara sulit dihindari dengan dasar memberi keuntungan bagi para pihak, baik pemegang kuasa maupun aparatur penegak hukum dengan elit pemerintahan baik tingkat pusat maupun lokal, artinya satu sama lain saling berkerjasama. Kondisi ini merupakan dampak buruk pelaksanaan penegakan hukum lingkungan akibat politik desentralisasi, yakni terjadinya kewenangan yang salah kaprah.

Berdasarkan kajian tersebut di atas, terlihat kewenangan daerah dalam penegakan hukum lingkunngan bidang usaha tambang di kabupaten Bungo Provinsi Jambi cukup signifikan. Hal akibat sistem otonomi daerah telah memberi kuasa yang amat besar kepada Kepala Daerah dalam pemberian izin pertambangan batubara. Disinyalir kewenangan tersebut sudah disalahgunakan oleh Kepala Daerah dengan berkerjasama dengan aparat penegak hukum di kabupaten Bungo. Salah satu isu yang mencuat akhir-akhir ini adalah Bupati beri izin terima Rp.15M sebagai kompensasi.

Penegakan gukum lingkungan dalam hal pertambangan batubara di Kabupaten Bungo, sangat dipengaruhi sistem pemerintahan daerah dengan mendistribusikan kewenangan dan kuasa yang besar kepada kepala daerah dalam bentuk pemberian izin pertambangan batubara di kabupaten Bungo. Ketentuan tersebut terdapat dalam penerbitan dan 
pencabutan izin tambang yang berada ditangan Bupati sebagai Kepala Daerah yang diatur dalam Pasal 37 UU Minerba.

\section{Penguatan Kelembagaan Masyarakat Adat di Kabupaten Bungo}

Keberadaan terhadap masyarakat hukum adat yang berada di Kabupaten Bungo di atur dalam, Peraturan Daerah Kabupaten Bungo Nomor 5 Tahun 2007 Tentang Lembaga Adat Melayu (LAM) yang mana LAM memiliki fungsi dan tugas:

1. Mengamankan;

2. Memelihara;

3. Menginventarisasi;

4. Mengurus; dan

5. Memanfaatkan sumber kekayaan alam.

yang mana kelima fungsi dan tugas dari LAM tersebut adalah untuk memanfaatkan keseluruhan sumber daya alam tersbeut duntuk hal meningkatkan kesejahteraan bagi seluruh masyarakat Kabupaten Bungo.

Dikarenakan sangat kompleks dan rumit dalam hal penegakan hukum lingungan yang melibatkan masyarakat hukum adat atas dasar kepentingan umum (algemen belang : public interst), yang berkaitan dengan terjadinya tumpang tindih penegakan hukum yang mana instrumen dalam penegakan hukum nasional dan hukum adat berbeda, yang berkaitan dengan pertambangan batubara. Gatot Supramono menyampaikan bahwa, dalam hal kegiatan pertambangan batubara harus dapat menyesuaikan terhadap perubahan lingkungan strategis yang terjadi untuk mendorong tumbuhnya otonomi daerah yang baik, serta terwujudnya Hak Asasi Manusia (HAM) yang berkeadil dalam hal mengelola hukum lingkungan dan pastinya dengan melakukan pelibatan terhadap peran masyarakat.

Berdasarkan Peraturan Daerah Kabupaten Bungo Nomor 5 Tahun 2007, sudah memberikan pemerintah daerah secara normatif terhadap masyarakat adat dan kelembagaan LAM dalam hal penegakan terhadap hukum lingkungan dalam bidang pertambangan batubara di Kabupaten Bungo. Kegiatan pertambangan batubara yang merupakan sumber kekayaan alam, masyarakat adat yang tersingkirkan akibat adanya politik sumberdaya alam yang berjalan sejara represif, sentralistik dan menimbulkan ketidak adilan terhadap masyarakat hukum adat di Kabupaten Bungo.

Kondisi seperti ini yang mampu menimbulkan konflik ditengah masyarakat lokal/adat dengan para pengusaha tambang batubara pada lokasi pertambangan batubara yang terdapat di Kabupaten Bungo. Namun berdasarkan analisis dari peneliti Pemerintah Kabupaten Bungo terlihat memihak kepada pemilik modal dengan dasar Pendapatan Asli Daerah (PAD) daerah. Hal mi memicu terjadinya konflik terhadap tambang batubara sebagai kekayaan alam yang berujung pada kekerasan antara masyarakat adat/lokal terhadap penyelemggara pemerintahan daerah dan pemilik modal yang melibatkan aparat penegak hukum berlindung pada IUP yang diberikan oleh pemerintah daerah. Konflik inilah yang dapat menimbulkan pelanggaran terhadap HAM masyarakat hukum adat terhadap hak-hak masyarakat adat atas kekayaan alam pertambangan batubara yang dimiliki oleh Kabupaten Bungo dan setiap aksi protes dari masyarakat selalu berujung pada tuduhan anti-pembangunan.

Konflik horizontal tersebut dilatarbelakangi lokasi tambang yang diklaim masyarakat adat tanah ulayat mareka dan/atau disebut sengketa lahan dengan para pemegang IUP/WIUP izinnya dikeluarkan oleh para Bupati. Problematika hukum ini sering terjadi akibat izin WIUP dan IUP yang dikeluarkan para Bupati berada di wilayah hukum masyarakat adat dan anehnya tidak melibatkan masyarakat lokal/adat terhadap izin lokasi tambang batubara tersebut. Konsekuensi sengketa lahan tidak bisa dihindari antara pemegang IUP/WIUP dengan masyarakat lokal/adat. Dalam kondisi seperti ini, posisi masyarakat adat lemah dan cendrung diperlakukan sewenang-wenang dengan berbagai kasus yang muncul dibeberapa desa Kabupaten Bungo.

Berkaitan dengan UU Minerba yang telah penulis sampaikan di atas, masyarakat yang terkena dengan dampak negatif lansung dari penyeelenggraan kegiatan pertambangan batubara memiliki hak untuk mendapat ganti rugi yang layak dari penyelenggaraan kegiatan pertambangan batubara tersebut. Ganti rugi yang dimaksud apabila terjadi kesalahan dalam kegiatannya, yang mengakibatkan terganggunya kegiatan masyarakat di sekitar daeraj pertambangan tersebut. Yang berdampak mempengaruhi kesejahteraan masyarakat karena adanya kegiatan pencemaran lingkungan baik berupa banjir, polusi dan banyak lainnya yang mengganggu kesejahteraan masyarakat. UUPPLH menegaskan masyarakat yang mengalami kerugian akibat pencemaran dan/atau kerusakan lingkungan berhak mengajukan gugatan melalui perwakilan kelompok atau class action untuk memperoleh keadilan.

Berdasarkan kajian yang penulis paparkan di atas, terdapat keterkaitan terhadap penegakan hukum lingkungan dalam bidang pertambangan batubara di Kabupaten Bungo, dapat dilakukan melalui penguatan kelembagaan masyarakat melalui LAM. Dalam konteks ini penulis mengacu pada teori efektifitas penegakan hukum yang dikemukan Soejono Soekamto, ada 5 (lima) hal pokok mempengaruhi efektifitas atau tidak berfungsinya penegakan hukum, yaitu substansi hukum, aparat penegakan hukum, sarana dan/atau prasarana, budaya hukum masyarakat, kesadaran hukum masyarakat; 
Relevan dengan teori efektifitas yang dikemukan Soejono Soekamto tersebut, dalam penegakan hukum lingkungan bidang usaha tambang batubara di Provinsi Jambi, faktor yang tidak kalah pentingannya "penguatan kelembagaan masyarakat adat". Artinya, penulis menambahkan teori efektifitas yang dikemukan Soejono Soekamto dalam penegakan hukum lingkungan bidang usaha tambang batubara melalui konsep penguatan kelembagaan masyarakat adat. Hal ini sangat penting dan seharusnya menjadi perhatian oleh pemerintah dan aparat penegak hukum agar tidak terjadinya diskriminatif dalam penegakan hukum (law enforment) dan berfungsinya hukum dalam penerapannya.

Pada kejadian seperti ini akan terlihat bahwa hukum efektif terhadap masyarakat kelas menengah. Diskriminatif ini terjadi dalam penegakan hukum lingkungan bidang usaha tambang batubara di Kabupaten Bungo. Dengan adanya pengaturan tentang penggunaan hak atas tanah sebagai kegiatan usaha pertambangan, merupakan ketentuan hukum secara yuridis formal yang merupakan bentuk konkret penghormatan atas hak-hak masyarakat setempat atau hak ulayat/adat yang selama ini sepertinya diabaikan oleh pemerintah. Berkaitan dengan kegiatan eksplorasi dan eksploitasi terhadap kegiatan pertambang batubara, masyararakat seharusnya lebih layak mendapat perlindungan karena masyarakat adat sudah pasti hidup bergantung kepada kekayaan alam dan sumber daya alam yang ada di daerah masyarakat lokal/adat tersebut. Sehingga hal ini akan memunculkan pranata hukum untuk dapat melakukan pengelola alam dan sumber daya akam secara baik dengan berlandaskan pada kearifan lokal yang sejalan dengan pelestarian sumber daya alam dan hukum nasional.

Kegiatan galian pertambangan yang berada di Kabupaten Bungo banyak terjadi penyimpangan, contohnya tidak ada permintaan persetujuan masyarakat adat atas kegiatan galian pertambang batubara di lokasi yang berbatasan dan berada pada daerah masyarakat lokal/adat tersebut. Bahkan pemegang IUP/WIUP batubara lansung melakukan kegiatan galian tambang batubara tanpa persetujuan masyarakat lokal/adat dilokasi tambang tersebut, dengan hal seperti ini Pemerintah Kabupaten Bungo telah mencederai hak atas tanah masyarakat adat yang, dengan dalih meningkatkan devisa negara dan PAD Daerah.

Berdasarkan yang telah dipaparkan di atas menurut kajian dan pengamatan oleh penulis dalam hal penerapan penegakan hukum lingkungan pada bidang pertambang batubara agar tidak mengganggu masyarakat adat/lokal sebaiknya dapat dilakukan melalui penguatan kelembagaan masyarakat adat dan LAM yang harus dilakukan penyesuaian terhadap ketentuan hukum adat masyarakat setempat dengan melalui perizinan kepada LAM, ketua adat dan/atau masyarakat adat dan tentunya hal ini sesuai dengan yang terdapat dalam Pasal 18B ayat (2) Undang-Undang Dasar 1945 yang merupakan landasan konstitusi yang pluralis di Indonesia.

Berdasarkan ketentuan di atas hal ini akan membuat eksistensi dari kelembagaan masyarakat hukum adat di Kabupaten Bungo dalam penegakan hukum lingkungan pertambang batubara dapat dijadikan sebagai sarana hukum dan secara jelas kinstitusi telah mengatur keberadaan masyarakat hukum adat termasuk pula hukum yang menjadi pedoman hidup bagi masyarakat hukum adat. Dengan dilibatkannya masyarakat hukum adat dan LAM diharapkan pula adanya pembentukan peraturan perundang-undangan nasional maupun daerah terutama yang berkaitan dengan pengelolaan sumber daya alam dan kekayaan alam yang terdapat di setiap daerah dapat dijadikan sumber hukum dalam kerangka penguatan kelembagaan masyarakat adat dalam penegakan hukum lingkungan yang melibatkan LAm dan tidak menganggu tatanan kehidupan dari mastarakat hukum adat.

\section{SIMPULAN}

Penegakan hukum terhadap pertambangan batubara di Kabupaten Bungo sulit diwujudkan, dikarena dipengaruhi oleh beberapa faktor, yaitu faktor yuridis normatif, faktor aparatur penegak hukum, artinya apatur penegak hukum diskriminatif dalam hal law enforcement dan faktor yang bersifat yuridis sosiologis, arti menyangkut pertimbangan ekonomis mempengaruhi fungsi penegakan hukum budaya masyarakat belum efektifnya dalam penegakan hukum lingkungan Kabupaten Bungo. Untuk itu konsep penguatan kelembagaan masyarakat adat dalam penegakan hukum lingkungan bidang usaha tambang batubara perlu diwujudkan dalam sistem hukum pertambangan batubara dan dapat dilakukan melalui pengawasan, baik pengawasan represif maupun preventif membatu pemerintah daerah dalam penegakan hukum lingkungan bidang pertambangan di Kabupaten Bungo.

\section{DAFTAR PUSTAKA}

\section{Buku}

Abrar Saleng. Kuasa Pertambangan Dalam Perspektif Hukum Administrasi Negara. Dalam Buku Dimensi-dimensi Pimikiran Hukum Administrasi Negara. Yogyakarta: UII Press, 2001.

\section{Jurnal}

Fenty U. Puluhulawa, "Kewenangan Perizinan Dalam Pengelolaan Lingkungan Pada Usaha Pertambangan", Jurnal Hukum, Fakultas Hukum Universitas Hasanundin, No.5, Vol.IX, (2014): 76. 
Hayatul Ismi, "Pengelolaan Sumber Daya Alam Mineral dan Batubara", Jurnal Ilmu Hukum Universitas Riau, No.2, Vol.4, (Februari 2017): 102.

Martha Pigone, "Politik Hukum Pertambangan Indonesia dan Pengaruh pada Pengelolaan Lingkungan Hidup di Era Otonomi Dearah”, Jurnal Hukum, Jakarta, Desember, No.3, Vol.15, (2003): 27.

Salim HS, "Hak Menguasai Negara atas Minerba, Pasca Berlakunya Undang-undang Minerba". Jurnal Konstitusi, No.3,Vol.9, (2002): 126.

Soni Heri Prasetyo, "Menata IUP, Membenahi Industri Minerba. Artikel, Minerba", majalah Dirjen Minerba, Jakarta, Maret, No.7, Vol.5, (2004): 124.

\section{Peraturan Perundang-Undangan}

Undang-Undang Dasar Negara Republik Indonesia Tahun 1945.

Undang-Undang Nomor 4 Tahun 2009 tentang Mineral Batubara.

Undang-Undang Nomor 23 Tahun 2014 Tentang Pemeritahan Daerah.

Peraturan Daerah Kabupaten Bungo Nomor 5 Tahun 2007 tentang Lembaga Adat Melayu. 